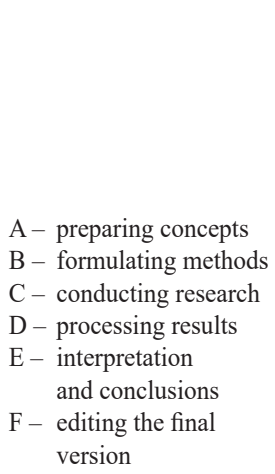

\section{The incidence of osteopenia among men with different levels of physical activity}

\section{Występowanie osteopenii u mężczyzn o zróżnicowanym poziomie aktywności fizycznej}

\author{
Anna Kopiczko ${ }^{1 A-F}$, Karol Gryko ${ }^{1 \star A-F}$, Monika Łopuszańska-Dawid ${ }^{1 B-D, F}$, \\ James J Laskin $2 \mathrm{E}-\mathrm{F}$ \\ ${ }^{1}$ Faculty of Physical Education, Jozef Pilsudski University of Physical Education, \\ Warsaw, Poland; Wydział Wychowania Fizycznego, Akademia Wychowania \\ Fizycznego Józefa Piłsudskiego w Warszawie, Polska
}

${ }^{2}$ ASEAN Fulbright Scholar, Dir., New Directions Wellness Center, School of Physical Therapy \& Rehabilitation Sciences, University of Montana, Missoula,USA

Key words: bone density, physical fitness, body build, bone mass

\title{
Abstract
}

Introduction: The aim of this study was to estimate the bone mass (BM) and bone mineral density (BMD) of the non-dominate forearm and compare these measurements to basic features of somatic structure and habitual physical activity (PA) levels in adult men.

Material and methods: The study examined 160 men aged 20 to 50, randomly sampled from Warsaw, Poland. Bone mineral density and BM of the forearm was measured with dual energy x-ray absorptiometry. Anthropometric measurements included: height, body mass, and the width of the elbow and wrist of the non-dominant limb. Habitual PA was assessed by the International Physical Activity Questionnaire.

Results: The men with sufficient to high levels of PA demonstrated normal values for the T-score in the both the distal and proximal forearm measurement sites in more than $90 \%$ of participants and more than $50 \%$ in the those with sufficient level of PA. In the group with insufficient levels of PA, low values of the T - score indicating osteopenia was found in both the proximal and distal measurement sites, $71 \%$ and $80 \%$ respectively. Significant, though weak positive correlations were found between BMD, an indicator of $\mathrm{T}$ - score, and a both elbow and wrist widths.

Conclusions: Lack of PA is clearly associated with an increased occurrence of osteopenia and osteoporosis in men. This study supports the notion that osteopenia and osteoporosis is present in younger adult men and that sufficient habitual PA is a important factor to preserve bone health.

email: k.gryko@awf.edu.pl

The study was conducted as part of the DS-272 statutory grant of the Jozef Pilsudski University of Physical Education in Warsaw

Badania zostały przeprowadzone w ramach działalności statutowej DS-272 Akademii Wychowania Fizycznego Józefa Piłsudskiego w Warszawie 


\section{Streszczenie}

Wstęp: Celem badania była ocena masy kostnej (BMC) i gęstości mineralnej kości (BMD) niedominującego przedramienia oraz porównanie tych zmiennych z wybranymi cechami budowy somatycznej u dorosłych mężczyzn o różnym poziomie aktywności fizycznej (PA).

Materiat $i$ metody: Zbadano 160 mężczyzn z Warszawy w wieku od 20 do 50 roku życia. Gęstość mineralną i masę tkanki kostnej przedramienia zmierzono metodą absorpcjometrii rentgenowskiej DXA. Przeprowadzono pomiary wysokości i masy ciała oraz szerokości łokcia i nadgarstka niedominującej kończyny górnej. PA oceniono na podstawie Międzynarodowego Kwestionariusza Aktywności Fizycznej (IPAQ).

Wyniki: U mężczyzn o wystarczającym i wysokim poziomie PA odnotowano prawidłowe wartości wskaźnika T-score w odcinku dystalnym, a w proksymalnym u ponad $90 \%$ badanych oraz u ponad $50 \% \mathrm{w}$ grupie o wystarczającym poziomie PA. W grupie o niewystarczającym poziomie PA, zarówno w bliższym, jak i dalszym miejscu pomiaru, zaobserwowano niskie wartości T-score (odpowiednio o $71 \%$ i $80 \%$ ), wskazujące na osteopenię. Istotną dodatnią korelację stwierdzono między BMD, wskaźnikiem T-score, a szerokościami łokcia i nadgarstka.

Wnioski: Brak aktywności fizycznej wyraźnie wiąże się ze zwiększonym ryzykiem występowaniem osteopenii i osteoporozy u mężczyzn. Badanie to potwierdza, że osteopenia, czyli obniżona gęstość mineralna kości, może wystąpić już u młodych mężczyzn. Regularna aktywność fizyczna jest istotnym czynnikiem dla zachowania zdrowia kości.

\section{Słowa kluczowe:}

gęstość kości, aktywność fizyczna, budowa ciała, masa kostna

\section{Introduction}

Little is known about the determinants of bone mineral density (BMD) in young adults. Most studies have focused on the bone mass (BM) and BMD of postmenopausal women or the elderly. However, considering that adult BMD is dependent on the peak bone mass (PBM), which is reached during adolescence or as a young adult, evaluating the factors affecting BMD, particularly in men, is worthwhile [1].

The human skeleton is considered to be the structural support system for the body, the site of muscle attachment, protects the internal organs, and is a storehouse of calcium, phosphorus and magnesium. The skeleton is formed by two types of bone: cortical (compact), which is on the surface of the bone and is predominant in the shafts of long bones and cancellous (spongy or trabecular), which comprises the bulk of the mass of short and flat bones, but is also present in the interior of long bones [2].

The human skeleton is constantly remodeling, including bone growth phase of consolidation and involution of bone tissue. A significant impact on bone mineralization occurs during childhood and adolescence. Accelerated bone skeleton construction lasts until about the age of 20. During this time, 90$95 \%$ of BM and BMD are accumulated [3].
In later stages of ontogenetic development there is constant bone loss associated with the loss of trabecular bone and resorption of bone from the marrow cavity. The rate of bone loss is dependent on gender. Women will lose $35-50 \%$ of the cancellous bone and $25-30 \%$ of cortical bone, and men respectively $15-45 \%$ and $5-15 \%$. In men, the loss of trabecular bone begins after reaching PBM, and the loss of cortical bone starts later and is associated with a decrease in physical activity (PA), sexual hormones, and bioavailability; therefore, leading to increased bone turnover [4-6].

For proper bone mineralization the following is particularly important: adequate calcium intake, regular exercise, proper physical development and growth of muscle mass. The value of PBM is affected by intrinsic factors (genetic, race, gender, body composition) and exogenous (diet, physical activity, nutritional status, medication use, chronic diseases).

The bone mass depends, among other things, on such factors as body weight, diet and adequate dosing of physical activity. A number of studies have demonstrated the positive correlation between body weight and body mass index (BMI) on BMD due to their impact on remodeling bone by increasing the mechanical loading state of the bones [7-9]. Body weight has also been identified in several reports as a predictor of PBM [10,11]. 
The determinants of the normal development of bone tissue, the differences are emphasized in BMD and gender-based bone size. It is believed that in men there is a lower risk of fracture, because in general they have a higher BMD than women regardless of age. The larger periosteal circumference in males compared women may be the result of increased mechanical load caused by the increased BM and body surface area in men [12]. Despite this, osteoporosis in men is considered a major public health problem.

Physical activity is an important element of human lifestyle. Regular PA results in positive changes in every system in the body. For the skeletal system, regular PA results in improved BMD and optimal $\mathrm{BM}$, strengthens and stabilizes joint structures, maintains range of motion, strengthens the muscles, tendons and ligaments. Physical activity affects the muscular system by increasing the cross-sectional area and volume of muscle fibers, increases the tension, strength and elasticity of the muscles.

Osteopenia (and potentially osteoporosis) is a serious public health problem due to its effects on morbidity and mortality particularly in the older population. Studies on habitual PA throughout the lifespan have revealed a correlation between BMD and osteoporosis risk. Unfortunately these areas of research have primarily focused on female and aging populations in developed countries [13].

To begin to address the paucity of data in men, the aim of this study was to evaluate BM, BMD of the forearm as related to selected somatic traits and the habitual PA of adult men.

\section{Material and methods}

\section{Participants}

The study involved 160 men aged 20 to 50 . Using a population register a random sample of men in Warsaw was obtained. All the men participating in the study gave their informed consent to participate in a research project and were informed about the study and test methods. The inclusion criteria consisted of: no contraindications to densitometry, no history of thyroid disease, cancer, rheumatoid arthritis or longterm treatment with glucocorticosteroids. The study was conducted in from September to December 2015.

\section{Procedures and measures}

The BM, BMD and limb width of the nondominant proximal radius/ulna and distal radius/ulna was measured by dual energy x-ray absorptiometry (DXA) (Norland). From this data the T-score was calculated. The World Health Organization definition of osteoporosis is based on the T-score. The T-score is a comparison of a patient's BMD to that of a healthy thirty-year-old of the same sex and ethnicity (expressed in standard deviations). In addition, body height, body weight and the width of the elbow and the wrist were measured using standard anthropometric procedures. [14,15].

Habitual PA was evaluated using the International Physical Activity Questionnaire (IPAQ), Polish version. The IPAQ short version was used as recommended by the European Health Interview Survey (EUROHIS), European Physical Activity Surveillance System (EUPASS). This estimation of weekly PA was carried out using the direct interview method. All interviews were conducted by the same trained interviewer. The interview was preceded by a question regarding to what extent the last 7 days were typical of the respondent in order to confirm the repeatability and also to eliminate individuals whose recent PA was atypical (e.g. sick or in hospital).

Weekly PA was calculated by summing the Metabolic Equivalent of Task (MET) values obtained during intense activity, moderate and walking performed during the previous 7 days. The methodology of assessing the level of weekly PA using the IPAQ distinguished 3 categories. Low or Insufficient PA, is when the total energy expenditure is less than 600 MET min/week. Moderate of Sufficient PA is considered when the total energy expenditure is between 600 and $1500 \mathrm{MET} \mathrm{min/week,} \mathrm{assuming}$ that this was a result of three or more days of intense PA for at least 20 minutes per day; 5 or more days of moderate activity or walking for not less than $30 \mathrm{~min}$, or a combination of intense or moderate $\mathrm{PA}$, that results in at least $600 \mathrm{MET} \mathrm{min} /$ week. Physical activity is considered High, when the total energy expenditure is greater than $1500 \mathrm{MET} \mathrm{min} /$ week and results from at least 3 days of intensive effort or 30 minutes moderate PA or walking on 5 or more days [16].

\section{Statistical Analysis}

All analysis were performed using STATISTICA (v. 10 , Stat. Soft. USA). In order to investigate the nature of the distribution of the results the Shapiro-Wilk test was conducted. In case of rejecting the assumptions of normality of the assessment distribution of the significance of diversity we used the nonparametric Kruskal-Wallis test. Levene's test was used to evaluate 
the homogeneity assumption needed for ANOVA. Given equal variances across a factorial ANOVA and Tukey test (post-hoc) for unequal numbers was performed. In the case of unequal variances the Kruskal-Wallis test for independent data would be performed. In order to determine the relationship between the forearm BM and BMD, T-score, body height, body weight, and the width of the elbow and wrist a Pearson correlation analysis was performed. The study wide alpha was set at $\mathrm{p}<0.05$.

\section{Results}

Somatic characteristics of men in relation to the assessed levels of PA is shown in Table 1. Men with high PA, demonstrated significant differences ( $p$ $<0.05$ ) with wider elbows and wrists (respectively by $4.2 \%$ and $3.6 \%$ ) than those with insufficient levels of PA. The mean values of BMI, height and weight were not significantly different regardless of the level of habitual PA.

Tab. 1. Characteristics of somatic of men with the level of physical activity

\begin{tabular}{|c|c|c|c|c|}
\hline \multirow{3}{*}{ The analyzed variables } & \multicolumn{4}{|c|}{ Level of physical activity } \\
\hline & $\begin{array}{c}\text { All } \\
(\mathrm{n}=160)\end{array}$ & $\begin{array}{c}\text { Insufficient } \\
(\mathrm{n}=80)\end{array}$ & $\begin{array}{l}\text { Sufficient } \\
(\mathrm{n}=20)\end{array}$ & $\begin{array}{l}\text { High } \\
(\mathrm{n}=60)\end{array}$ \\
\hline & \multicolumn{4}{|c|}{ mean $\pm \mathrm{SD}$} \\
\hline Age (years) & $28.9 \pm 9.1$ & $32.8 \pm 10.3$ & $27.5 \pm 6.7$ & $24.0 \pm 4.9^{* * * t *}$ \\
\hline Body height $(\mathrm{cm})$ & $180.7 \pm 7.5$ & $180.3 \pm 7.3$ & $178.2 \pm 6.9$ & $181.9 \pm 7.6$ \\
\hline Body mass (kg) & $82.0 \pm 14.3$ & $84.1 \pm 15.0$ & $79.8 \pm 16.1$ & $80.1 \pm 12.3$ \\
\hline $\operatorname{BMI}\left(\mathrm{kg} / \mathrm{m}^{2}\right)$ & $25.2 \pm 4.2$ & $25.9 \pm 4.6$ & $25.2 \pm 5.1$ & $24.3 \pm 3.1$ \\
\hline elbow width (cm) & $7.2 \pm 0.5$ & $7.1 \pm 0.5$ & $7.2 \pm 0.5$ & $7.4 \pm 0.5^{*}$ \\
\hline wrist width $(\mathrm{cm})$ & $5.7 \pm 0.5$ & $5.6 \pm 0.3$ & $5.7 \pm 0.5$ & $5.8 \pm 0.7^{*}$ \\
\hline
\end{tabular}

$* \mathrm{p}<0.05, * * * \mathrm{p}<0.001$

The comparison of the measured characteristics of bone in relation to BMI and PA is presented in Table 2. Men characterized as obese demonstrated a significantly lower (36.8\%) T-score in the proximal forearm bones compared to those with a normal BMI. Men with high levels of PA demonstrated significantly greater values of $\mathrm{BM}, \mathrm{BMD}$ and T-scores as compared to those with sufficient and insufficient PA levels. Those with at least sufficient levels of PA demonstrated distal T-scores in the favorable ranges of this value of the indicator.

Tab. 2. Relationship bone characteristics to Body Mass Index and the level of habitual physical activity.

\begin{tabular}{|c|c|c|c|c|c|c|c|}
\hline \multirow{2}{*}{\multicolumn{2}{|c|}{$\operatorname{BMD}\left(\mathrm{g} / \mathrm{cm}^{2}\right)$}} & \multicolumn{3}{|c|}{ Distal R/U } & \multicolumn{3}{|c|}{ Proximal R/U } \\
\hline & & \multirow{2}{*}{$\frac{\mathrm{BM}(\mathrm{g})}{0.473}$} & \multirow{2}{*}{$\begin{array}{c}\text { T-score } \\
2.090\end{array}$} & \multirow{2}{*}{$\frac{\operatorname{BMD}\left(\mathrm{g} / \mathrm{cm}^{2}\right)}{0.357}$} & \multirow{2}{*}{$\begin{array}{c}\mathrm{BM}(\mathrm{g}) \\
0.887\end{array}$} & \multirow{2}{*}{$\frac{\text { T-score }}{2.629}$} & \multirow[b]{2}{*}{$-1.026 *(3)$} \\
\hline \multirow{3}{*}{ BMI } & 1. Normal & & & & & & \\
\hline & 2. Overweight & 0.497 & 2.118 & 0.426 & 0.898 & 2.596 & -1.059 \\
\hline & 3. All Obesity & 0.462 & 1.966 & -0.02 & 0.858 & 2.462 & $-1.404 *(\mathbf{1})$ \\
\hline \multirow{3}{*}{$\begin{array}{l}\text { Level } \\
\text { of physical } \\
\text { activity }\end{array}$} & 4. Insufficient & 0.435 & $1.927 * *(6)$ & $-0.329 * *(6)$ & $0.842 *(\mathbf{5})$ & $2.412 * *(6)$ & $-1.559 *(\mathbf{5}) * *(\mathbf{6})$ \\
\hline & 5. Sufficient & $0.458 * *(6)$ & $1.993 * *(6)$ & $0.161 * *(6)$ & $0.891 *(4) * *(6)$ & $2.549 * *(6)$ & $-1.052 *(\mathbf{4}) * *(\mathbf{6})$ \\
\hline & 6. High & $0.538 * * \mathbf{5})$ & $2.309 * * \mathbf{4 , 5})$ & $1.232 * *(4,5)$ & $0.941 * * \mathbf{5})$ & $2.862 * *(4,5)$ & $-0.472 * * \mathbf{( 4 , 5 )}$ \\
\hline
\end{tabular}

$* \mathrm{p}<0.05 ; * * \mathrm{p}<0.01, \mathrm{BMI}$ - body mass index, BMD - bone mineral density, BM - bone mass, $\mathrm{R} / \mathrm{U}$ - radius and ulna

Given the level of PA (Table 3) it is clear that a high or sufficient PA level, resulted in a distal $\mathrm{T}$-score in the normal range. However, only $55 \%$ of those with sufficient PA levels, demonstrated normal proximal T-scores whereas this was observed in over $90 \%$ of those engaged in high levels of PA. Only $20 \%$ of those men with insufficient PA levels demonstrated a standard T-score in the normal range, the majority of others demonstrated values that indicated osteopenia. 
Tab. 3. Distribution of T-scores based on location of assessment across physical activity levels.

\begin{tabular}{|c|c|c|c|c|c|c|}
\hline \multirow{4}{*}{ Level of physical activity } & \multicolumn{6}{|c|}{ T-score } \\
\hline & \multicolumn{2}{|c|}{$\begin{array}{c}\text { Norm } \\
(>-0.99)\end{array}$} & \multicolumn{2}{|c|}{$\begin{array}{c}\text { Osteopenia } \\
(>-1 \text { to }<-2.49)\end{array}$} & \multicolumn{2}{|c|}{$\begin{array}{l}\text { High risk of osteoporosis }(< \\
-2.5)\end{array}$} \\
\hline & Dis. & Prox. & Dis. & Prox. & Dis. & Prox. \\
\hline & \multicolumn{6}{|c|}{$\%$} \\
\hline All $(n=160)$ & $90 \%$ & $51.3 \%$ & $10 \%$ & $44.4 \%$ & $0 \%$ & $4.3 \%$ \\
\hline Insufficient $(\mathrm{n}=80)$ & $20 \%$ & $19.9 \%$ & $80 \%$ & $71.3 \%$ & $0 \%$ & $8.8 \%$ \\
\hline Sufficient $(\mathrm{n}=20)$ & $100 \%$ & $55.0 \%$ & $0 \%$ & $45.0 \%$ & $0 \%$ & $0 \%$ \\
\hline $\operatorname{High}(n=60)$ & $100 \%$ & $91.7 \%$ & $0 \%$ & $8.3 \%$ & $0 \%$ & $0 \%$ \\
\hline
\end{tabular}

Dis - distal, Prox - proximal

Table 4 examines the relationships between BMD, BM a with the measured somatic features. There was a significant but weak positive correlation BMD and both the width of the elbow and wrist. The same was true for BM. There was also a significant, though weak positive correlation between body height, and the BM of the both the proximal and distal measurement sites. Interestingly there was no association between body mass and any of the boney measurements.

Tab. 4. Correlations between bone mineral density, bone mass, forearm and T-score and somatic parameters.

\begin{tabular}{|c|c|c|c|c|c|c|c|c|c|}
\hline \multirow{2}{*}{\multicolumn{2}{|c|}{$\begin{array}{c}\text { Features bone } \\
\mathrm{r}\end{array}$}} & \multicolumn{2}{|c|}{ Body height $(\mathrm{cm})$} & \multicolumn{2}{|c|}{ Body mass (kg) } & \multicolumn{2}{|c|}{ Elbow width $(\mathrm{cm})$} & \multicolumn{2}{|c|}{$\begin{array}{l}\text { Wrist width } \\
(\mathrm{cm})\end{array}$} \\
\hline & & $\mathrm{p}$ & $\mathrm{r}$ & $\mathrm{p}$ & $\mathrm{r}$ & $\mathrm{p}$ & $\mathrm{r}$ & $\mathrm{p}$ & \\
\hline \multirow{3}{*}{ Dis $R / U$} & $\operatorname{BMD}\left(\mathrm{g} / \mathrm{cm}^{2}\right)$ & 0.168 & 0.034 & 0.109 & 0.172 & 0.353 & 0.000 & 0.290 & 0.000 \\
\hline & $\mathrm{BM}(\mathrm{g})$ & 0.132 & 0.097 & 0.064 & 0.420 & 0.234 & 0.003 & 0.204 & 0.010 \\
\hline & T-score & 0.177 & 0.025 & -0.014 & 0.863 & 0.391 & 0.000 & 0.309 & 0.000 \\
\hline \multirow{3}{*}{$\operatorname{Prox} \mathrm{R} / \mathrm{U}$} & $\operatorname{BMD}\left(\mathrm{g} / \mathrm{cm}^{2}\right)$ & 0.137 & 0.083 & 0.014 & 0.862 & 0.245 & 0.002 & 0.179 & 0.009 \\
\hline & $\mathrm{BM}(\mathrm{g})$ & 0.206 & 0.009 & 0.013 & 0.875 & 0.199 & 0.012 & 0.261 & 0.001 \\
\hline & T-score & 0.103 & 0.196 & -0.040 & 0.612 & 0.310 & 0.000 & 0.211 & 0.001 \\
\hline
\end{tabular}

$\mathrm{r}$ - coefficient of rank Pearson, $\mathrm{p}$ - alpha, Dis - distal, Prox - proximal, R/U - radius and ulna, BMD - bone mineral density, $\mathrm{BM}$ - bone mass

\section{Discussion}

Age-related changes in mineral content (BMC) in the skeleton are determined by both genetic factors and environmental characteristics for any given population. The state of bone tissue is mediated by many factors. This study highlights the important relationships of indicators of bone health to both somatic characteristics and the level of habitual PA [17]. BMI is seen by many authors as an important predictor of BMD and BMC in both women and men. As pointed out by Compston et al. [18], a low BMI is a well-accepted risk factor for low BMD and consequently an increased risk for osteoporotic fractures. Conversely, a larger BMI seems to be protective of bone tissue. In our study, the mean BMI in men was 25.2, which indicates being overweight. However, those men who were overweight or obese did not demonstrate significantly greater BM and BMD as compared to men with normal BMI [19]. Though not significant, overweight men in the current study demonstrated the highest levels of BMD in both the distal and proximal forearm measurement sites. However in women, Beck et al. [19] found that those with a higher BMI had significantly higher femoral $\mathrm{BMD}$, as well as a more robust geometry.

On the other hand, Zhao et al. report that obesity, while may result in a higher BMI, is often associated with excess adipose tissue which can have a negative effect on the bone, as associated with the secretion of hormones derived from the adipocyte inflammatory cytokines that adversely affect the bone metabolism [20]. In our study, obesity was not the factor that determined the highest BMD and better T-score values, but rather PA level.

The relationship between body height and BM are associated with the overall health and condition of the skeleton. In the current study, these Polish men from Warsaw demonstrated a significant, 
though weak positive correlation between body height of BM in both the proximal aspects of their non-dominate forearms. Also, significant, though weak positive correlations occurred between BMD and the hallmarks of the massiveness of the skeleton (the width of the elbow and wrist) in both distal and proximal measurement sites. The width of the elbow and wrist correlated positively with BM in the distal section. In the proximal portion while said positive relationship only the width of the elbow. With the same weight there was no significant correlation of BMD and BM.

The first large population studies of PA in adult Poles was carried out by Drygas et al. [21]. They found that $37 \%$ of women and $32 \%$ of men failed to meet even the sufficient PA activity level as defined by the IPAQ. This state of affairs concern health professionals and epidemiologists, since there is a clear association between PA and greater $\mathrm{BM}$ and BMD better of both the peripheral and axial skeleton [22-24]. Studies have indicated that men engaged in high and sufficient levels of PA, demonstrate normal T-score values, especially in the distal aspects. Those with insufficient levels of PA, present with T-scores characteristic of osteopenia in both proximal and distal limb aspects, $71 \%$ in $80 \%$ respectively. Therefore these studies demonstrate that a high or sufficient levels of PA were associated with a higher BM and BMD [22-24].

The impact of exercise on the rate of bone loss is an important research topic. In the ten-year prospective population studies of the Swedes, Daly et al found that men and elderly women, who maintained an active lifestyle in the 10 years prior to the study, were characterized by reduced bone loss and better balance than peers who remained inactive [25]. A study on 326 men aged 50 years and older revealed that regular PA in the prior 10-20 years as well as leisure PA in the preceding 12 months correlated positively with BMD of the femoral neck, trochanter and lumbar spine, and this correlation was independent of age and BMI [26].

In terms of PA Poles fall below the average for the countries of the European Union [27]. As indicated in the report TNS Poles show the greatest sporting activity to 25 years of age. After thirty years of age, this activity is gradually falling, to rise again in the group 60+. In our study, as in previous studies of physical activity Polish population [28] found decreased levels of PA with age. High levels of PA were characterized by the youngest study participants, and insufficient oldest, who formed the largest group.

Resisting the typical decline in PA with age is a key issue in the prevention of osteoporosis. Physical activity PA slows involution of the bone and appears to be one of the most important factors in environmental modeling and reconstruction of skeletal metabolism $[29,30]$

\section{Conclusion}

Bone mass and BMD of the non-dominant forearm showed a significant relationship between the level of PA and the selected characteristics of somatic build. Insufficient PA is associated with a higher incidence of osteopenia in men.

There is a need expand our osteoporosis education programs to men. Educating men on the importance of using PA to improve BM and BMD is critical to the prevention of osteoporosis.

\section{References}

1. Bianchi ML. Osteoporosis in children and adolescents. Bone. 2007;41(4):486-95.

2. Martin TJ, Seeman E. Bone remodelling: its local regulation and the emergence of bone fragility. Best Pract Res Clin Endocrinol Metab. 2008;22:701-22.

3. Parfitt AM, Travers R, Rauch F, Glorieux FH. Structural and cellular changes during bone growth in healthy children. Bone. 2000;27(4):487-94.

4. Compston JE. Counteracting bone fragility through improved bone quality. Medicographia. 2002;24:290- 6 .

5. Gracia- Lorda P, Salas- Salvo J, Fernandez Ballart J, Murphy MM, Bullo M, Arija V. Dietary Calcium and Body Mass Index in a Mediterranean Population. Int. J Vitam Res. 2007;77(1):34-40.

6. Riggs BL, Melton LJ, Robb LA, Camp JJ, Atkinson EJ. A Population-Based Assessment of Rates of Bone Loss at Multiple Skeletal Sites: Evidence for Substantial Trabecular Bone Loss in Young Adult Women and Men. J Bone Miner Res. 2008;23:205-14.

7. Reid IR. Relationships among body mass, its components and bone. Bone. 2002;31:547-55. 
8. Porthouse J, Birks YF, Torgerson DJ, Cockayne S, Puffer S, Watt I. Risk factors for fracture in a UK population: a prospective cohort study. QJM. 2004;97:569-74.

9. Mussolino ME, Gillum RF. Low bone mineral density and mortality in men and women: the Third National Health and Nutrition Examination Survey linked mortality file. Ann Epidemiol. 2008;18:847-50.

10. Cadarette SM, Jaglal SB, Murray TM, Mc Isaac WJ, Joseph L, Brown JP. Evaluation of decision rules for referring women for bone densitometry by dual-energy x-ray absorptiometry. JAMA. 2001;286:57-63.

11. Hawker GA, Jamal SA, Ridout R, Chase C. A clinical prediction rule to identify premenopausal women with low bone mass. Osteoporos Int. 2002;13:400-6.

12. Havill LM, Mahaney MC, Binkley TL, Specker Bonny L. Effects of Genes, Sex, Age, and Activity on BMC, Bone Size, and Areal and Volumetric BMD. JBMR. 2007;22(5):737- 46.

13. Coupland CAC, Cliffe SJ, Bassey EJ, et al. Habitual physical activity and bone mineral density in postmenopausal women in England. Int J Epidemiol. 1999;28:241-6.

14. Lochman TG, Roche AF, Martorell R. Anthropometric Standardization Reference Manual, Human Kinetics Books, Illinoi, USA 1988.

15. Hall JG, Allanson JE, Gripp KW, Slavotinek AM. Handbook of Physical Measurements. Oxford University Press 2007.

16. Biernat E, Stupnicki R, Gajewski AK. Międzynarodowy Kwestionariusz Aktywności Fizycznej (IPAQ) - wersja polska. [International Physical Activity Questionnaire - polish version]. Wychow Fiz i Zdr. 2007;6-7:4-9. Polish.

17. Duda B, Wójtowicz E. Poziom aktywności fizycznej a gęstość mineralna kości w odcinku lędźwiowym kręgosłupa u osób w wieku średnim. Medycyna Ogólna i Nauki o Zdrowiu. 2014;20(3):291-5.

18. Compston JE, Flahive J, Hosmer DW, Watts NB, Siris ES. Relationship of Weight, Height, and Body Mass Index With Fracture Risk at Different Sites in Postmenopausal Women: The Global Longitudinal Study of Osteoporosis in Women (GLOW). JBMR. 2014;29:487-93.

19. Beck TJ, Petit MA, Wu G, LeBoff MS, Cauley JA, Chen Z. Does obesity really make the femur stronger? BMD, geometry, and fracture incidence in the women's health initiative-observational study. J Bone Miner Res. 2009;24(8):1369-79.

20. Zhao LJ, Jiang H, Papasian CJ, Maulik D, Drees B, Hamilton J, Deng HW. Correlation of obesity and osteoporosis: effect of fat mass on the determination of osteoporosis. J Bone Miner Res. 2008;23(1):17-29.

21. Drygas W, Kwaśniewska M, Szczęśniewska D, Kozakiewicz K, Głuszek J, Wiercińska E. Ocena poziomu aktywności fizycznej dorosłej populacji Polski. Wyniki programu WOBASZ. Kardiologia Polska. 2005;63:1-5.

22. Dionyssiotis Y, Paspati I, Trovas G, Galanos A, Lyritis GP. Association of physical exercise and calcium intake with bone mass measured by quantitative ultrasound. BMC Women's Health. 2010;10:12.

23. Camhi SM, Katzmarzyk PT. Total and femoral neck bone mineral density and physical activity in a sample of men and women. Appl Physiol Nutr Metab. 2012;37:947- 54.

24. Karlsson MK, Rosengren BE. Training and bone - from health to injury. Scand J Med Sci Sports. 2012;22:15- 23.

25. Daly RM, Ahlborg HG, Ringsberg K, Gardsell P, Sernbo I, Karlsson MK. Association Between Changes in Habitual Physical Activity and Changes in Bone Density, Muscle Strength, and Functional Performance in Elderly Men and Women J Am Geriatr Soc. 2008;56:2252- 60 .

26. Florindo AA, Latorre Mdo R, Jaime PC, Tanaka T, Pippa MG, Zerbini CA. Past and present habitual physical activity and its relationship with bone mineral density in men aged 50 years and older in Brazil. J Gerontol A Biol Sci Med Sci. 2002;57(10):654-7.

27. Special Eurobarometer 412. Sport and physical activity. European Commission, Directorate-General for Education and Culture and co-ordinated by Directorate-General for Communication 2014.

28. Bergier B. Place and role of physical activity in the lives of the elderly and disabled people. Health Problems of Civilization. 2014;2(8):10-14.

29. Lohman T, Going S, Pamenter R. Effects of resistance training on regional and total bone mineral density in premenopausal women: A randomized prospective study. J Bone Miner Res. 1995;10:1015-24.

30. Shephard RJ. Aging, Physical Activity, and Health. Hum Kin Publ. Champaign 1997. 